\title{
From discourses about language-in-education policy to language practices in the classroom-a linguistic ethnographic study of a multi-scalar nature in Timor-Leste
}

\section{Ildegrada da Costa Cabral ${ }^{1}[$}

Received: 29 February 2020 / Accepted: 10 September 2020 / Published online: 16 December 2020 (c) The Author(s) 2020

\begin{abstract}
This article makes the case for conducting ethnographic research of a multi-scalar nature that links language policy processes and ideologies of language with everyday practices, on the ground, in local schools and classrooms. As with other researchers engaged in the ethnography of language policy (e.g. McCarty, 2011; Johnson, 2013), my concern is with the ways in which language policies in multilingual countries are translated into classroom practice, the ways teachers and school administrators understand and respond to policy changes and the ways in which communication between teachers and learners is shaped by the introduction of a new medium of instruction. The research presented here focuses on language policy and classroom practice in Timor-Leste. On Independence in 2002, Tetum and Portuguese were chosen to be the two official languages of the country and the main languages of teaching and learning in the school system. My main research sites have been primary schools and classrooms in Timor-Leste and I have adopted a linguistic ethnographic approach, combining ethnography with close analysis of classroom discourse and with discourse analysis of policy documents and interviews. I have used the concept of language ideology as an analytical lens in examining the language policy discourses of policymakers and teachers. Teachers in Timor-Leste are regarded by policymakers as the mere facilitators of the process of implementing Tetum and Portuguese language-in-education policy within the education system. Through the analysis of interview data presented here, I show that teachers assumed this role and shared the belief that Tetum and Portuguese were legitimate official languages of Timor-Leste. Then, through analysis of codeswitching in classroom interaction, in one Year 6 classroom, I show how values around Tetum and Portuguese were being discursively constructed by the teacher, particularly in talk around monolingual texts in Portuguese.
\end{abstract}

Keywords Bilingual education · Postcolonialism · Multi-scalar approach · Linguistic ethnography $\cdot$ Language ideologies $\cdot$ Codeswitching 


\section{Introduction}

This article presents a multi-scalar approach to the language-in-education policy processes that have been unfolding in primary schools in Timor-Leste since independence. It draws on linguistic ethnographic research that was carried out in Dili, the capital city, in 2012. It was conducted during the celebrations of the 10th anniversary of independence.

The study makes a contribution to the growing body of empirically-informed, classroom-based studies of multilingual practices (for recent reviews, see Lin 2008, 2013; Martin-Jones 2015; Bonacina et al. forthcoming). It also contributes to research into language policy processes that is grounded in the theoretical and methodological framework of linguistic ethnography (Rampton 2007; Copland and Creese 2015; Snell et al. 2015). In addition, it contributes to the development of sociolinguistic and ethnographic research in educational contexts where different varieties of Portuguese are used, in text and talk, in tandem with other linguistic resources (e.g. Carneiro 2015; da Costa Cabral 2019; Chimbutane 2011, 2013, 2019; Keating 2019; Solovova 2019).

The interdisciplinary tradition that has been developed within the field of linguistic ethnography enabled me to engage in detailed analysis of the ways in which different language resources were drawn upon in the daily interactional routines of primary classroom life in Timor-Leste. It also enabled me to build an understanding of the trajectories of the teachers participating in my study, through close engagement with them, and to grasp the ways in which their views of language policy have been shaped over time. At the same time, a linguistic ethnographic approach enabled me to investigate wider policy processes and to identify the range of language ideologies that were circulating at the time among social actors positioned on different institutional scales, from the Ministry of Education to local primary classrooms. This made it possible to show how these policy processes and language ideologies were often indexed in the day to day interactional practices of the teachers and students in the primary school classrooms in my study.

Before moving on to introduce the content of this article, it is necessary to add a brief word here about my own positionality as a researcher undertaking this study. I am a woman of East-Timorese origin, who grew up in Portugal from the age of five. I speak both Tetum and Portuguese, the two official languages of Timor-Leste today and, in family circles in Portugal and Timor-Leste, I have become familiar with the ways in which resources from each language are mixed and blended in the everyday conversations that take place in local life worlds. My mother was a primary school teacher, and my father was a civil servant, during the latter years of the Portuguese colonial order in Timor-Leste. My family moved to Portugal as refugees after the Indonesian invasion. As I grew up in Portugal, I became increasingly aware of the nature and extent of the political, social, cultural and linguistic challenges facing the East-Timorese people, in Timor and in the diaspora, who were committed to the struggle for independence. When I finally undertook this study in 2012, in the independent nation of Timor-Leste, I was fortunate that I was able to gain access to the school in which my research was carried out through personal networks. But, at the 
same time, I was keenly aware that I had not experienced life under the Indonesian occupation, like the different social actors participating in my study. This reinforced the need for me to observe the key principle of ethnography: That of aiming to gain access to the emic perspectives and values of those participating in my study. I also worked as a teacher in Portugal before I began my doctoral research, so I felt a particular professional empathy with the teachers participating in my study.

In the first section of this article, I show how language ideologies provide us, as researchers, with a way of making connections between the views about language policy articulated by different social actors positioned on different scales and language practices 'on the ground' in local schools and classrooms. In the second section, I consider the notion of codeswitching and I review classroom studies that have been conducted in different postcolonial contexts. In section three, I briefly describe language-in-education policy developments after independence in TimorLeste, focusing on the decade between 2002 and 2012. My aim here is to delineate the socio-political context for the study that I carried out. In section four, I offer an account of the design and conduct of the study. Section five focuses on discourses at the political level regarding the role of the two official languages of instruction within the East-Timorese school system. Section six presents an analysis of extracts of multilingual classroom discourse that were audio-recorded in a Year 6 classroom in a school in Dili. The extracts reveal the ways in which the classroom teacher and her pupils drew on resources from the two official languages, Tetum and Portuguese, in order to make sense of the content of a monolingual school text in Portuguese. In the seventh and final section, I make some concluding remarks.

\section{Multi-scalar approaches to the ethnography of language-in-education policy}

Many contemporary studies in sociolinguistics are based on the idea that sociolinguistic phenomena on the scale of face-to-face interaction in multilingual contexts need to be explained with reference to the wider social and institutional context. For over two decades, within the field of language-in-education policy, scholars have been committed to demonstrating the benefits of investigating how policy-related practices and ideologies unfold, on a local scale and on a regional and national scale (e.g. Ricento and Hornberger 1996; Heller and Martin-Jones 2001; Blommaert 2007; Hornberger and Johnson 2007; McCarty 2011; Johnson 2009, 2013; Hult 2015; Tollefson and Pérez-Milans 2018). This research has provided us with detailed insights into the different ways in which social actors are positioned on different scales. In this article, I build on this tradition. I aim to illustrate the ways in which the language ideologies (Schieffelin et al. 1998; Woolard 1998) of the participants in my study-ideologies which were indexed in interviews and in the teacher talk in the classroom-were bound up with their own personal trajectories, with the socio-historical context of the country, and with discourses circulating about language on a national scale, in political and institutional domains. I thus show how interrelated discourses about Tetum and Portuguese traversed different scales of language policy-making in Timor-Leste. 
As Heller and Martin-Jones (2001) point out, the concept of language ideologies provides a means to understand how the multilingual practices and beliefs of teachers and discourses of policymakers at the national or institutional level are shaped by hegemonic views about language, and its role in education, and how particular situated processes of language legitimation operate in postcolonial states in connection with national development, 'internationalization' and 'globalization'. Writing in a similar vein, Blackledge (2000) argues that language ideologies include "the values, practices and beliefs associated with language use by speakers, and the discourse that constructs values and beliefs at state, institutional, national and global levels" (p. 29).

According to Heller (2007), the investigation of bilingualism as an ideology and practice means recognising and deconstructing the view of bilingualism as ideologized in "the coexistence of two linguistic systems" (p. 1). She proposes the term "parallel monolingualism" to refer to forms of educational policies, programmes and linguistic practices in which two languages are seen as fixed and bounded 'codes' and kept separated from one another. This contributes to the ideological construction of bilingualism as two separate monolingualisms.

As Lin (2013) has pointed out, hegemonic ideologies about language, language use, and language learning/teaching still shape language-in-education policy in many contexts in the global south. Blommaert (2006) illustrates how this view of language has spread and how the discipline of linguistics, and structuralist approaches to language have contributed to its dissemination. In his words: "Linguistics has contributed in no small degree to the cultural construction of language in general as a stable, contextless individual mental object, and language and educational policies as well as larger nation-building programs have been deeply influenced by this ideology." (p. 512). Commenting on the views of language underpinning nation-building projects, Heller (2006) says that "the imagining of the nation includes ideological struggles over its most central values, and these struggles take place not only with respect to what monolingualism and multilingualism represent, but also to the very shape of the language to be privileged" (p. 10).

Timor-Leste has a bilingual education policy, yet the two languages involved (Tetum and Portuguese) do not have equal social value. Similar hierarchies of language occur in other postcolonial contexts where official languages, a European language and a local language, are both used in different institutional spaces. For instance, in his work in Tanzania, Blommaert (1994) analysed the metaphors of 'development' and 'modernization' that were used with regard to Kiswahili and other Tanzanian languages in one particular journal after the independence of the country (p. 213). The 'developed' languages were languages such as English, French or German, while Kiswahili was considered to be a 'developing' one.

More recently, Chimbutane (2011) undertook an ethnographic study of bilingual education in a postcolonial context in Mozambique. He carried out the study in two primary schools where two African languages, Changana and Chope, were used as the media of instruction alongside Portuguese. The focus was on 5 bilingual classrooms that were involved in the transitional phase of this bilingual programme. He noted that the teachers varied in the ways in which they used Changana or Chope and/or enabled students to use these languages in Portuguese-medium classes and 
in the Portuguese language lessons in the bilingual programme. Portuguese was constructed as a highly prestigious and legitimate language by the teachers, while Changana and Chope were assigned a much lower status in the classroom.

\section{Researching classroom codeswitching and the construction of legitimate language}

As Heller and Martin-Jones (2001) showed in an early edited volume, with contributions from researchers working in schools in different settings around the world, the reproduction and contestation of linguistic ideologies and hierarchies takes place in and through the daily round of interactional life in classrooms. Creese (2008) also notes that, as a site of interaction, a classroom is "a cultural context with its own sites of struggle and its own local institutional imperatives and affordances for particular kinds of learning and interaction" (p. 235). So, in this section, I focus on the concept of codeswitching-one that was used in the founding studies of multilingual classroom talk (e.g. Hornberger 1988; Zentella 1981). I argue that it assists us in building an understanding of interactional practices, and in interpreting and analysing the ways in which these practices contribute to the shaping of the relationships that develop in classrooms between teachers and pupils, and the specific situated nature of the meaning-making practices related to texts and textbooks. As Jaffe (2003) pointed out in her research in Corsican classrooms, texts shape bilingual practices and, at the same time, bilingual practices mediate the texts that are used.

In sociolinguistics, there is an ongoing academic movement around the notion of 'languaging' which aims to reconceptualise bilingual/multilingual practices as going beyond the social construction of languages as separable and autonomous entities. It is argued that, in people's everyday life worlds, languages are used in fluid and complex ways and resources from different languages are often blended, even within a single utterance. Moreover, in this approach, the focus is on speakers, rather than on named languages. Speakers are seen as using diverse linguistic resources in order to communicate and make meaning in the different situations in which they find themselves. Polylingual languaging (Jørgensen 2008), translanguaging (García 2009; Blackledge and Creese 2010; Creese and Blackledge 2015), metrolingualism (Otsuji and Pennycook 2010), and translingual practices (Canagarajah 2013) are some of the terms introduced by sociolinguists investigating multilingual practices in late modern contexts.

Despite the value of this alternative terminology for research into communication in local life worlds, in the context of the increasing diversity of urban neighbourhoods in large cities e.g. in Europe and North America, these terms, and particularly the term translanguaging, do not adequately capture the reality of the classrooms that I observed in the post-colonial educational setting of Timor-Leste. As I will show later, in the Year 6 classroom in my study in Timor-Leste, Portuguese and Tetum were being discursively constructed by teachers, through their day to day codeswitching practices, as two bounded and separate entities. Classroom-based language practices such as these are not unique to Timor-Leste. In the two paragraphs that follow, I will briefly allude to two other examples of research in post-colonial 
contexts, in South Asia and in South-East Asia, where such practices were documented and where explanatory accounts were provided with reference to the wider political and ideological contexts in which they occurred.

In his study in Jaffna in Sri Lanka, Canagarajah (2001) showed how the study of everyday codeswitching by teachers and pupils in the classroom in multilingual contexts can provide understandings of the ways in which teachers and pupils negotiate dominant ideologies and, at the same time, index their own identities and values. In his study in Jaffna, he found that teachers' pedagogy and the recurrent teacher-pupil and pupil-pupil codeswitching were a way to respond to local conditions and were due to the existing tensions between two political and cultural groups, that is Tamil and Singhalese speakers. He also interpreted the codeswitching practices of the participants in his study as a subtle form of resistance to those who had established the language policy. Through their codeswitching practices, participants detached themselves from the Tamil-only policy and incorporated the linguistic and cultural pluralism of local Tamil social life into their classroom conversations.

Cincotta-Segi (2011) conducted a study of classroom talk in primary schools in minority language settings in northern Laos, where the majority of the population speak Kmhmu. She describes the ways in which centrality was given to the official national language, the Lao language, in the lessons and activities of one teacher, while ample use was made of the Kmhmu language in mediating Lao texts for the students. She emphasises that in this teacher's classroom, the goal was clearly to "work from the Lao language curriculum in the mother tongue of the students in order that they would be able to engage successfully in the activity." (p. 26).

In the classes I observed in my study in Timor-Leste, teaching also developed around the textbook. Luke (1988) draws attention to the fact that pupils do not have direct and personal access to the knowledge underpinning the text, and emphasise that the teacher is the one who mediates the knowledge presented in the text. Codeswitching was the main communicative strategy deployed by the teacher to mediate the textbook in the classroom described later in this article. According to Gumperz (1982), codeswitches serve as contextualisation cues, along with other communicative resources such as lexical choices, prosody or gestures. Contextualisation cues are the key resources for negotiating meanings in interaction. Participants use them to make inferences about what is going on, to signal how their contributions are to be understood and to evaluate the significance of contributions by others. Writing about the metaphorical aspect of human communication, Gumperz (1982) argued that contextualisation cues can index particular values, ideologies, identities, relationships or shared worlds of experience, adding further layers of meaning to what is already being said. Moreover, as Martin-Jones (1995) has observed, besides employing codeswitching for additional meaning-making in regular sequences of interaction, teachers and pupils in bilingual classrooms also consider each other's proficiency in the languages used in the interaction to accomplish lessons.

My interest in the work around codeswitching derives from a need to understand how codeswitching operates in the transmission of legitimised institutional knowledge and how it contributes to the reproduction of or resistance to the social hierarchies and linguistic ideologies which are embedded in language-in-education policy discourses. 


\section{Post-independence language-in-education policy in Timor-Leste (2002-2012)}

On independence in 2002, the new East-Timorese government defined Tetum, one of the national languages and the most widely spoken one, and Portuguese, as the two official languages of the country. The status of different languages was set out in Section 13 (Constituent Assembly 2002) of the Constitution as follows:

\section{Section 13 (Official languages and national languages)}

1. Tetum and Portuguese shall be the official languages in the Democratic Republic of East Timor.

2. Tetum and the other national languages shall be valued and developed by the State $^{1}$

\section{Section 159 (working languages)}

Indonesian and English shall be working languages within civil service side by side with official languages as long as deemed necessary.

http://timor-leste.gov.tl/?cat=37\&lang=en

It is crucial to mention that the sociolinguistic transformations that took place in the history of the territory of Timor-Leste were bound up with political processes, including Portuguese colonialism (1515-1975), the Indonesian invasion and occupation (1975-1999) and the East-Timorese Resistance to the Indonesian occupation. The choice of Portuguese and Tetum as official languages, in particular Portuguese, caused intense controversy among the East-Timorese, in the foreign press (particularly in Australia), and in research circles in the early years of independence (Leach 2008; Taylor-Leech 2009). Elite social actors explained at the time what their views about Portuguese in Timor-Leste were. For instance, Xanana Gusmão who was the first President of Timor-Leste stated at the IV Conference of the Heads of State and Government of the Community of Portuguese Speaking Countries (CPLP) in 2002 that "Portuguese is our historic identity which was paradoxically assigned to us by colonial presence” ("O Português é a nossa identidade histórica, que ironicamente nos foi concedida pela presença colonial.") (Vidal Soares 2011, p. 97).

The implementation of the first phase of language-in-education policy was supported through bilateral agreements with Portugal, and later with Brazil (Nicolai 2004; Makoni and Severo 2015) (see also the article by Alan Carneiro, this Special Issue). Over time, there have been changes in policy directives regarding the use of Portuguese and Tetum as the media of instruction in schooling. These are described in detail by Taylor-Leech (2013). In 2003, the Ministry of Education began work on a new curriculum for primary education. The design and implementation of this curriculum was also carried out with donor assistance. The primary funding came from UNICEF and the curriculum was designed in collaboration with educationalists from a Portuguese university (Shah 2012). The first reference to the simultaneous use of Portuguese and Tetum as the languages of instruction appeared in the

\footnotetext{
1 Tetum is also spoken in one of the regions of Timor-Leste. There is it known as Tetum Terik.
} 
Education Policy Framework of 2004-2009 (MECYS 2004). From then on, one of the curriculum objectives was to develop the two official languages "at the same time in a process of mutual enrichment" (p. 8). It was also recommended that Tetum could be used as a "pedagogic aide" (p. 11), together with Portuguese, at the basic levels of education.

The collaboration between Timor-Leste and other countries such as Portugal with regard to education and the development of the Portuguese language in Timor-Leste was reinforced in political discourse years after independence. Ramos-Horta, the second President of Timor-Leste, from 2007 to 2012, affirmed to a Portuguese news article called Público that "In the future, the relationship with Portugal should be more oriented to education and training. We cannot overload Portugal with other requests. It is a friend but we cannot put it in such a difficult situation." ("No futuro, as relações com Portugal devem ser mais orientadas para a educação e a formação. Não podemos sobrecarregar Portugal com outros pedidos. É um país amigo mas não o podemos colocar nessa situação difícil.”) (Moura 2007).

In 2008, the Ministry of Education (2008) of the newly elected government finally provided explicit educational guidelines on the use of the two official languages as media of instruction from Year 1 to Year 4. The ratio of the use of Portuguese and Tetum was established in these guidelines for each school year.

\begin{tabular}{ll}
\hline Year 1 & 70\% Tetum, 30\% Portuguese \\
Year 2 & 50\% Tetum, 50\% Portuguese \\
Year 3 & 30\% Tetum, 70\% Portuguese \\
Year 4 & 0\% Tetum, 100\% Portuguese \\
\hline
\end{tabular}

From Year 4, the language of instruction and writing was to be Portuguese, whilst Tetum was to be a language for spoken instruction only. Another important policy development in 2008 was the introduction of the Lei de Base do Sistema Educativo 14/2008 (the Education System Framework Law). This document established the structure of the education system and made important references to the objectives for education especially, with regard to the official languages. These objectives were stated there as follows:

- The teaching languages of the Timorese education system are Tetum and Portuguese (p. 6, Article 8).

- Mastery of the Portuguese and Tetum languages should be ensured (p.9, Article 12).

These objectives represented important moves towards the definition of the role of the two official languages as media of instruction, not prioritising Portuguese only, but attributing to both Portuguese and Tetum a relatively equal status at the educational policy planning level. Taylor-Leech (2013) considered Lei de Base to be a key planning document which contributed to opening up spaces for the use of not only Tetum but also the 'national languages' in education. 
Other planning documents were approved from 2008 onwards. These led to the emergence of a new set of discourses with regard to the use of the children's 'mother tongues' that is the languages designated as 'national languages' in the Constitution. Cabral (2013) and Taylor-Leech (2013) discuss in depth the ideas and discourses underpinning these planning documents and, the subsequent debates and positions taken up by different groups in civil society regarding the 'mother tongue' issue.

In May 2012, the new President of Timor-Leste, Taur Matan Ruak, at his inaugural ceremony emphasised and consolidated the role of Portuguese as an official language of the country. He affirmed that Portuguese had a political and strategic role to play in the country, as well as being emblematic of national identity (Press: Público). He also made a personal critical point, arguing that the teaching of Portuguese should assume methodologies appropriate to the teaching of a foreign language rather than that appropriate to teaching a 'mother tongue'. At that time, during the period of fieldwork on which this article is based, there were Portuguese and Brazilian educators running teacher training programmes, for East-Timorese teachers, at universities in Timor-Leste. Textbooks and teaching materials were produced in Portugal. They were to be used in classrooms across the country, as part of a collaboration between education and language specialists from Portugal and TimorLeste. Alan Carneiro conducted his research in the same period as me (see his article in this special issue). He investigated the evolution of the Portuguese and the Brazilian cooperation projects regarding university-level teacher training in TimorLeste. In his article for this special issue, he examines the views of three social actors involved in the undergraduate course for training Portuguese Language teachers, offered at UNTL (Universidade Nacional de Timor-Leste/National University of Timor-Leste): one Portuguese teacher, one Brazilian and one East-Timorese.

Makoni and Severo (2015) use the notion of 'Lusitanization', i.e. the spread of Portuguese colonial ideology, in their article on the role of Portugal and Brazil in post-colonial countries such as Angola and Timor-Leste. The authors argue that "The strong presence of Brazilian Portuguese teachers and language teaching methodologies in East Timor must be viewed within the context of Lusitanization." (p. 157). Despite this presence of both Portuguese and Brazilians in Timor-Leste, Makoni and Severo (2015) mention that the question about which variety of Portuguese should be promoted in Timor-Leste is unsettled, so in certain situations there is a mixture of Brazilian Portuguese, European Portuguese and East Timorese Portuguese. In his article in this special issue, Carneiro indicates how this issue was resolved, in favour of European Portuguese.

\section{A linguistic ethnographic study of a multi-scalar nature in Timor-Leste}

My study was designed as a multi-sited ethnography in order to investigate the ways in which the national language-in-education policy of Timor-Leste was being interpreted by social actors positioned on different scales. On the national scale, my aim 
was to provide accounts of the discourses about language drawn upon by the different political actors in their interpretation of the language policy. On the local scale, my aim was to build an account of the multilingual meaning-making practices of teachers and students in local primary classrooms as they put the language policy into practice in their day to day interactions, and as they mediated texts and curriculum materials that had been produced in Portugal.

Following the tradition of research on linguistic ethnography (Rampton 2007; Copland and Creese 2015; Snell et al. 2015), participant observation and interviews were combined with analysis of talk-in-interaction. As Creese (2008, p. 233) puts it, within this tradition, analysis of different data sources endeavours to "combine close detail of local action and interaction as embedded in a wider social world". Moreover, the interdisciplinary research orientation of linguistic ethnography allows researchers to "look closely and look locally" at classroom interactional events while also taking account of wider power and ideological processes (Blackledge 2011, p. 123).

Two interviews in the study presented here were conducted at the national university of Timor-Leste, at the Parliament and at the Ministry of Education. The interviewees were conducted with elite social actors who were closely involved in language-in-education policy-making on the national scale. My main research site was a Catholic primary school in Dili. Over a period of 2 months, observations were conducted in a Year 6 classroom with two different teachers. In this article, I will focus only on one teacher who I will refer to as Teacher Lucia. The interactions between the teacher and her pupils were audio-recorded, transcribed and analysed. Informal conversations then took place after the lessons and interviews were conducted with the president of the school, the director of the school and the two teachers. In these ways, insights were gleaned into the personal trajectories of these participants and into their views about language in everyday life in Timor-Leste. All the participants in the different research sites in my study were asked about their views about the national policy documents.

In the two sections that follow, I draw on selected data from the wider linguistic ethnographic study conducted in Dili, the capital city of Timor-Leste, in 2012.

\section{The national scale and elite social actors: discourses about language-in-education policy}

In this section, I focus on interviews conducted with two of the elite social actors participating in the study. I will refer to them as Daniel Santos ${ }^{2}$ and Tomás Mota to preserve confidentiality. The interviews enabled me to build a picture of their backgrounds, including their own language-in-education experiences (in the past) and their trajectories during the years of the Timorese Resistance to the Indonesian occupation. I also probed their views about the current language-in education policy

\footnotetext{
${ }^{2}$ All names used in this article are pseudonyms so as to protect confidentiality.
} 
in Timor-Leste, along with the discourses about the relative value of Portuguese and Tetum underpinning their views.

Dr Santos completed his secondary education at a Portuguese-medium Catholic school in Dili. This school sustained the Portuguese national curriculum during the Indonesian occupation, up until the 1990s. Dr Santos received a degree in English Language Teaching completed in Indonesia and he had a post as an English teacher for some years in Dili. He was also awarded an MA and a PhD in the field of Linguistics by an Australian university. He is fluent in Mambae, Tetum, Portuguese, Indonesian and English. Since independence Dr Santos has been appointed to highranking academic and political positions.

Mr. Mota's schooling started with Portuguese as the medium of instruction. This continued until Year 6 and then it changed into Indonesian after the Indonesian invasion. He then took a distance learning programme run by an Indonesian university and graduated in English Language Teaching and Economics. He first worked as a teacher of English and Economics in a school in Dili and then became the head of that school. At a later date, Mr. Mota held an administrative post at the Ministry of Education, and worked there until 1999. After Independence, he continued to work at the Ministry and, in 2012, at the time of my fieldwork, he held a senior position there. He is a speaker of Makasae, Tetum, Indonesian, Portuguese and English.

The interview with Dr Santos was conducted in Portuguese and the one with Mr. Mota was conducted in Tetum. Both interviews were then translated into English. In preparing for the interviews, extracts of official policy documents regarding the provisions for different languages were selected and the two interviewees were asked to comment on them. One of the questions that I asked was based on an extract from the Base Law for Education where the following was written: "As línguas de ensino do sistema educativo timorense são o tétum e o português." (The languages of instruction in the Timorese education system are Tetum and Portuguese) (2008, p. 6, Article 8). The two interviewees were asked to provide their interpretation of this statement.

Extract 1 illustrates how Dr Santos commented on this extract. His account was based on the principle that education is an official activity of the state, so the state education system should place the use of the official languages at its heart. The position he took needs to be understood with reference to the fact that, from the outset, he had been involved in the political meetings regarding the formulation of national language policy.

\section{Extract 1: Interview with Dr Daniel Santos}

Era para pôr cada língua no seu devido lugar, enquanto línguas de instrução, a primazia devia ser atribuída às línguas oficiais. Agora no que diz respeito à qual das línguas oficiais a ser utilizada, em que âmbito, em que nível, para que disciplina, nós advogávamos desde sempre que a língua mais preparada para, digamos assim, o exercício da didática com todos os rigores, não é, rigor didático, rigor lógico, rigor de expressão linguística, etc. com mais tradição deveria ser o português. O português toma precedência quando, se, qual língua usar para que nível, para que âmbito, para que disciplina, etc. Com uma pequena nota que é, o tétum deve ser sempre dado a oportunidade para a sua experimentação pedagógica e didática, acompanhando sempre o português. 


\section{(...)}

Aí ele [tétum] tem que ir aproveitando-se né do português, que já tem centenas de anos de experimentação, de experiência, tem um nível de abstração maior, tem uma capacidade maior de transmissão, de acompanhamento da ciência e da tecnologia, portanto tétum tem um parceiro, um aliado em quem confiar para o seu futuro desenvolvimento, provado historicamente que já foi assim. E aí lembramonos de casos espalhados pelo mundo fora que as línguas sem prestígio internacional no encontro ou em confronto com o inglês acabam sempre por se sucumbir. E o tétum e o português tem provado exatamente o contrário, convivem, enriquecem-se e produzem um resultado tipicamente timorense. (Interview number 3-in Portuguese)

\section{Extract 1 (English translation)}

It was to give to each language its own place, as a language of instruction. Primacy should be given to the official languages. Now concerning the official languages to be used, in what area, at which level, in what subject, we always advocated that the most prepared language, let's say, for didactic use, with all the rigour, didactic rigour, logical rigour, rigour of linguistic expression, etc., with more tradition, should be Portuguese. Portuguese is a priority when it is used for each level, whatever the area, whatever the subject, etc. With one small remark, that is, Tetum should always be given an opportunity to be used pedagogically and didactically, on an experimental basis, accompanied always by Portuguese.

(...)

So, Tetum has to make good use of Portuguese which has already had hundreds [of years] of experimentation, of experience, it has a capacity to express higher level of abstraction, it has a higher capacity for transmission, for accompanying science and technology. Therefore, Tetum has a partner, an ally, whom it can trust for its future development, it has been proved by history that it has been like that before. This brings to mind the cases around the world when languages, without international prestige, in contact or confrontation with English, always ended up succumbing [to its power], and Tetum and Portuguese have proved exactly the contrary, they coexist, they enrich each other and they produce an outcome that is typically Timorese. (My translation into English)

In Extract 1, we see that, in his response, Dr Santos acknowledged that the official languages of Timor-Leste, Tetum and Portuguese, should both be the languages of instruction given that education is an activity related to the state. However, he clearly valued them differently. He represented Portuguese as a distinct language system, as a 'code' with a long history, and as the most appropriate language of instruction. In contrast, Tetum was represented as being 'less developed', despite being an official language. At the same time, Tetum was characterized as having considerable symbolic value as an emblem of Timorese identity, along with Portuguese. Dr Santos also argued that the 'development' of Tetum in Timor-Leste could only be achieved by 'connecting' it to Portuguese. He illustrated this point by using the nouns "ally" and "partner" to refer to the development of the relationship between Tetum and Portuguese over time. He then strengthened this point by adding that the association of Tetum with Portuguese would prevent Tetum from dying out, as has happened with other languages with lower status in the world as a result of 'contact with' English. This concern expressed by Dr Santos was related to the fact that Australia is one of the countries neighbouring Timor-Leste and that some voices in Australia 
had been arguing for official status for English in Timor-Leste. So, he was making an oblique reference to the indigenous languages of Australia.

There has been an enduring discourse about the link between Tetum and Portuguese since the final years of the Timorese Resistance to the Indonesian occupation and during the preparations for Independence under the UN Administration from 1999 to 2002. Both languages also played an important role in the Resistance (Cabral and Martin-Jones 2008) and, over the years, Tetum has incorporated a substantial number of loan words from Portuguese. The discourse about the link between Tetum and Portuguese was most prominent in a speech given by an Australian linguist, Geoffrey Hull, who was closely involved in the establishment of the Instituto Nacional de Linguística (National Institute of Linguistics) in TimorLeste. The speech was given at the Congress of the Conselho Nacional da Resistência Timorense (CNRT-The National Council of the Timorese Resistance) which was held in Dili in August, 2000 (Hull 2000). In Extract 1 above, Dr Santos clearly oriented to this discourse as he argued that Portuguese would serve as a "partner, an ally" to Tetum, as Tetum was being developed as an official language. He represented the relationship between the two languages by personifying them as if they were social actors, with Portuguese acting in a supportive capacity vis-à-vis Tetum.

I turn now to Mr. Mota's comments on the quotation from the Base Law for Education in Extract 2.

Extract 2: Interview with Mr. Tomás Mota

Hanesan ohin ita koalia ona katak dehan ita nian pozisaun tuir portugués ho tetum ne'e sira rua nia nivel ne'e hanesan, entaun ita labele obriga mestre sira tem ke ho portugués 100 porsentu iha sala laran, maibé buat ne'e sei faze de aprosimasaun ne, faze de aprosimasaun. Livrus sira ne maka ami dehan tenta [inaudible] portugués hotu ona. Dala ruma sira bele le hamutuk ho alunus sira hotu portugués, alunus sira esplika mos bele agora dadauk, hau... ita le ho portugués hau bele esplika fali ho tétum mos bele iha. Ida ne'e mos bele akontese. (...) maibé ita agora ne'e se iha faze ida ke faze de konsolidasaun, ita labele obriga radikalmente, usik ba neneik, neneik neneik to'o, se to'o tempu ida ke professor hamrik iha sala de aula ne ho portugués hotu ona, ne'e se to'o tempu ida tan. (Interview in Tetum)

\section{Extract 2 (English Translation)}

So, as we were saying earlier on, I said that our position [was] to choose Portuguese and Tetum and that these two languages are the same, so we cannot force teachers to use Portuguese a hundred per cent [of the time] in the classroom, because we are still at an early stage, of approaching [our goals]. We are trying [inaudible] to have all books in Portuguese. Sometimes teachers can read with their pupils in Portuguese, to explain to pupils as we are doing now [referring to our joint discussion in Tetum of a legal text in Portuguese], I ... we read in Portuguese and I explain in Tetum, this can also happen [in the classroom] (...) Because we are now at a stage of consolidation, we cannot force radical [change], [we should] let it go slowly, very slowly until it gets to the time where the teacher is in the classroom with Portuguese only. But this time will come.

In his comments on the quotation, Mr. Mota made no mention of books in Tetum, but focused on the availability of books in Portuguese and on the current linguistic practices of teachers and pupils in the classroom. He also made the case for working bilingually in the classroom, with Portuguese being the main language and Tetum being used as an auxiliary language to clarify the meaning of texts in Portuguese. Since the textbooks are only in Portuguese, he acknowledged the role of Tetum in 
the current stage of the language policy implementation in schools in Timor-Leste. Yet he anticipated an era when there could be monolingual teaching in which Portuguese would be the only medium of instruction.

The two participants in this study shared the same broad views about Portuguese and Tetum. They supported the official language-in-education policy which allows for the use of both Portuguese and Tetum in the classroom, at this particular point in the history of Timor-Leste. However, they were of the view that Portuguese should be the main language of teaching and learning and Tetum should just serve as a pedagogic resource for teachers. Mr Mota envisaged a future scenario where classes would be conducted monolingually in Portuguese, while Dr Santos went further, providing a rationale for giving more emphasis to Portuguese and arguing that it constituted a more 'rigorous' means of expression than Tetum.

While their views about language policy were similar, there were differences in their discourses about language practices in local classrooms. Mr Mota took a pragmatic approach, saying: "we are now at a stage of consolidation, we cannot force radical [change]", and he acknowledged the challenges facing teachers who were working with school textbooks produced only in Portuguese. He seemed to be keenly aware of the lived experiences of teachers and their pupils in Timorese primary classrooms. Dr Santos mostly stressed that Portuguese was better suited to the building of knowledge since it was better 'prepared', more developed and had 'logical rigour'. He also implied that Tetum did not have these characteristics. Blommaert (1994) has commented on the dangers inherent in making such judgements about language and in adopting metaphors of 'development' to characterize languages:

Apart from the relative absurdity of a distinction such as 'developed-underdeveloped' for natural, widespread languages, there is the simple observation that a developed language is not a steady state object, but something dynamic. An underdeveloped language, can, therefore, never become 'developed', since the 'developed' languages themselves develop further (1994, p. 218).

These two interviews with elite social actors in Timor-Leste provide insights into the language ideologies that were prevalent among those who were closely involved in overseeing the implementation of language-in-education policy on a national scale at the time when my study was being carried out.

\section{Language-in-education policy processes on a local scale: discourses and practices}

I turn now to language policy developments on a local scale, in the school in Dili where I carried out my research. I focus first on the history of the school, on the aspirations of the families whose children attended the school and on the views of the school director. I then move on to an account of the language practices on the scale of the classroom. This section is illustrated with reference to the language practices of one teacher (Teacher Lucia) as she mediated for her pupils the content 
of a textbook in Portuguese. These practices are also considered in the light of the teacher's background and her beliefs about the language-in-education policy of Timor-Leste.

\section{The school, its history and the families it serves}

The Catholic school in my study is located in Díli. This school was created in the last years of the Indonesian occupation as part of a small, local neighbourhood project with twofold goals: to teach Portuguese and to attend to the needs of families by providing an education for their children. Lessons were first organised in private houses and out-of-doors under the trees. With an increased number of families wanting a place for their children after independence, the school expanded its facilities with the financial support of institutions and companies based in Portugal. It had about 700 students in 2012. Portuguese continues to be the medium of instructions although, in 2012, the overall director of the school also considered Tetum to be a valuable symbolic resource. He argued that every East-Timorese ought to know the two languages designated as 'official' in the national policy documents.

\section{One of the teachers, her trajectory, her views and values}

Teacher Lucia had received her education through the medium of Portuguese. During the Indonesian occupation, she had two roles within the Resistance: To supply food to the forces near the border with West Timor and to teach children and adults. Tetum and Portuguese were the medium of instruction. However, the Indonesian authorities arrested her and punished her by sending her to exile in a remote rural area, in the mountains. Under threat, she could not refuse the deportation. There she was required to start teaching due to the shortage of teachers who could teach through the medium of Indonesian. In 1986, she was ordered to return to her studies in Díli and train as a primary school teacher. Her teaching in Indonesian continued until 1999. At the time of my fieldwork, she had a heavy daily schedule since she was teaching in two schools. In the afternoon, she was teaching in the Catholic school and in the morning she was in another school teaching Mathematics.

In my interview with Teacher Lucia, I asked her to comment on the Decree-law of the Basic Education System, as I did with Dr Santos and Mr Mota. This is the Decree-law that states that both Portuguese and Tetum are the languages of instruction in schools in Timor-Leste. She replied that, since there is a legal requirement regarding the use of Tetum and Portuguese in schools, both should be used. She put her response as follows:

\section{Extract 6}

Isso é que agora há as escolas, e escolas para fortalecer essas línguas, essas línguas, para que todas as pessoas timorenses possam saber estas duas línguas, não só português, não só tétum, essas duas línguas devem acompanhar um ao outro para ter força, ter força, para não cair. (Interview with Teacher Lucia, in Portuguese) 
That is what schools are for now, to strengthen these languages, these languages, so that all Timorese people can learn these two languages, not only Portuguese, not only Tetum, but these two languages should accompany one another in order to be strong, to be strong, and not fall. (My translation into English)

Teacher Lucia was clearly committed to putting the national language-in-educational policy in practice. Echoing the account given by Dr Santos, she also argued that pupils' capabilities in both languages would be strengthened when the two languages were used together. We will see in the next section the ways in which Portuguese and Tetum were actively used in Teacher Lucia's classroom.

\section{The year 6 classroom: doing Environmental Studies and mediating texts in Portuguese}

The Year 6 class that Teacher Lucia was teaching had 46 pupils, 21 boys and 25 girls. They were 12 and 13 years old. Many parents of the children who attended this school were civil servants in Dili. The textbooks used in this classroom were produced in Portugal and were written in Portuguese. However, there were not enough textbooks for everybody.

When I was doing my fieldwork, Teacher Lucia was teaching a subject called Estudo do Meio (Environmental Studies, hereafter EM) to pupils in Year 6. EM is an interdisciplinary subject devoted to the development of themes related to the local environment in which pupils are situated. It incorporates perspectives from the social science and the natural sciences.

The teacher followed particular pedagogical practices and followed a 'standard script' in teaching from the textbook. This consisted of using the blackboard and teacher-student talk around a particular text from the textbook. The EM lessons I observed involved distinct teaching/learning activities, which were usually carried out in the same order: a summary of the lesson content was written the blackboard; the relevant text in Portuguese from the EM textbook was then written on the blackboard, since, as indicated above, there were some pupils who did not have a copy of the textbook; Teacher Lucia then focused on the language and content of different parts of the text, mostly by asking questions to the pupils. The question-and-answer routines were led by Teacher Lucia and the pupils responded to her questions either individually or in chorus (she seldom selected an individual pupil to provide a response).

The following extracts were taken from the transcript of one of the teaching/learning episodes that I video-recorded. This was a lesson about local means of transportation in Timor-Leste. Teacher Lucia and her pupils were talking about the following text in Portuguese from the textbook that had been written on the blackboard:

Os transportes são um fator importante na movimentação de pessoas e mercadorias de uma região para a outra. Em Timor-Leste, o transporte de passageiros interdistritos é assegurado por biskotas ${ }^{3}$.

3 'Biskota' (city bus) is an Indonesian term which has been in use since the Indonesian occupation. 
(English Translation: Forms of transportation are an important factor in the movement of passengers and merchandise from one region to another. In Timor-Leste, the transportation of passengers between the districts is guaranteed by city buses.)

Most of the interactions in this lesson were through the medium of Portuguese. However, after explaining the Portuguese text in Portuguese (as in Extract 3 , below), Teacher Lucia also provided explanations of the text in Tetum (as in Extracts 4 and 5).

Extract 3

\begin{tabular}{|c|c|c|c|}
\hline Line & & Original languages used & Translation into English \\
\hline $\begin{array}{l}109 \\
110 \\
111 \\
112 \\
113\end{array}$ & TL & $\begin{array}{l}\text { e vimos em Hali Laran biskota } \\
\text { aqui, biskota } \\
\text { [inaudible] que transporta os passageiros } \\
\text { no distrito, do distrito para distrito, } \\
\text { para Dí-? }\end{array}$ & $\begin{array}{l}\text { and we see city buses in Hali Laran } \\
\text { here, city buses } \\
\text { [inaudible] that transport the passengers } \\
\text { within the district, from district to district, } \\
\text { to Di-? }\end{array}$ \\
\hline 114 & PPS & Díli [many pupils speaking in chorus] & Dili [many pupils speaking in chorus] \\
\hline $\begin{array}{l}115 \\
116 \\
117 \\
118 \\
119 \\
120 \\
121 \\
122 \\
123 \\
124 \\
125 \\
126\end{array}$ & TL & $\begin{array}{l}\text { Díli também é um distrito/3/do distrito Díli } \\
\text { para distrito [inaudible]/2/do distrito } \\
\text { Ainaro para distrito Manatutu } \\
\text { para distrito Baucau } \\
\text { de Baucau para Díli } \\
\text { de Díli para Baucau } \\
\text { de Mantutu para Díli } \\
\text { e de Díli para Baucau } \\
\text { [in the background, voices of pupils } \\
\text { repeating what TL has just said] } \\
\text { que transporte as pessoas utilizam para vir } \\
\text { a Díli é a bisko-? }\end{array}$ & $\begin{array}{l}\text { Dili is also a district/3/from the district of Dili } \\
\text { to the district of [inaudible]/2/from the district } \\
\text { of Ainaro to the district of Manatutu } \\
\text { to the district of Baucau } \\
\text { from Baucau to Dili } \\
\text { from Dili to Baucau } \\
\text { from Manatutu to Dili } \\
\text { from Dili to Baucau } \\
\text { [in the background, voices of pupils repeating } \\
\text { what TL has just said] } \\
\text { what means of transportation do people use to } \\
\text { come to Dili, it's the city bu-? }\end{array}$ \\
\hline 127 & PPS & biskota [many pupils saying in chorus] & city bus [many pupils saying in chorus] \\
\hline
\end{tabular}

In Extract 3, teacher Lucia was focusing on the second sentence of the text she had written on the blackboard: "In Timor-Leste, the means of transportation of passengers between the districts is guaranteed by city buses". Firstly, she named some districts in order to give examples of movement from one district to another. Then she continued by asking what transport people used to come to Dili and elicited the correct response- "biskota" (city bus)—with a prompt of the 'complete my utterance' type. Apart from introducing the names of different districts, she mostly followed the wording of the sentence.

The following two extracts now illustrate the ways in which Teacher Lucia used Tetum to engage in this teaching/learning episode about the Portuguese text. 
Extract 4

\begin{tabular}{llll}
\hline Line & & Original languages used & Translation into English \\
\hline 138 & TL & em Tétum passageiros? & what is passengers in Tetum? \\
139 & FP & ema [response by a girl sitting in one of the & people [response by a girl sitting in one of the \\
140 & & front rows] & front rows] \\
141 & TL & refere ba se? & it refers to whom? \\
142 & PPS & ema [some pupils replying in chorus] & people [some pupils replying in chorus] \\
143 & TL & ema né bé sae & people [who] go on \\
144 & PP & sae [repeating in the background] & go on [repeating in the background] \\
145 & TL & transporte ba iha distritu ida & the transportation from one district to \\
146 & & ba distri-? & another distri-? \\
147 & PPS & distritu & district \\
148 & FP & distritu seluk [speaking loudly] & another district [speaking loudly] \\
149 & TL & inter-distritos & inter-districts \\
150 & & inter né katak dehan & inter means \\
151 & & ita né distritu la-? & between distr-? \\
152 & PPS & laran [many pupils replying in chorus] & districts [many pupils replying in chorus] \\
\hline
\end{tabular}

In Extract 4 the classroom conversation was again about the second sentence, and about the meaning of the word "passageiros" and a new term, "inter-distritos". The teacher-pupil interaction took place primarily in Tetum. This was the first moment in this lesson when Teacher Lucia and her pupils switched from Portuguese into Tetum in order to talk about the lesson content. The switch was triggered by Teacher Lucia's question in Portuguese: “em Tétum passageiros?" (what is passengers in Tetum?) (Line 138). This is was an explicit invitation to use Tetum. Several pupils clearly understood her invitation and replied immediately in Tetum, saying "ema" (people) (Line 139 and 142). Teacher Lucia continued using Tetum in her next three questions, only switching into Portuguese to say the word "inter-distritos" (Line 149) and moving back into Tetum to explain the meaning of "inter-distritos". This brief exchange finished with a choral response from the pupils in Tetum. This was elicited by Teacher Lucia's 'complete-myutterance' prompt in Tetum: "la-"(Lines 151 and 152).

In Extract 5, we see that Teacher Lucia then went on to talk about the first sentence, moving back and forth between Portuguese and Tetum.

Extract 5

\begin{tabular}{|c|c|c|c|}
\hline Line & & Original languages used & Translation into English \\
\hline 421 & TL & em tétum & in tetum \\
\hline 422 & & os transportes são um fator importante & forms of transportation are an important factor. \\
\hline 423 & & em Tétum é como? & In Tetum, what is it? \\
\hline 424 & & [inaudible-several pupils replying at the & [inaudible_-several pupils replying at the \\
\hline 425 & & same time; one girl was reading and & same time; one girl was reading and \\
\hline 426 & & emphasizing the nasal aspect of the & emphasizing the nasal aspect of the \\
\hline 427 & & Portuguese pronunciation] & Portuguese pronunciation] \\
\hline 428 & TL & importante, fator importante & important, an important factor \\
\hline 429 & & né fator bo’ot li-? & this is a very important fac-? \\
\hline
\end{tabular}




\begin{tabular}{|c|c|c|c|}
\hline Line & & Original languages used & Translation into English \\
\hline $\begin{array}{l}430 \\
431\end{array}$ & PPS & $\begin{array}{l}\text { bo'ot liu } \\
\text { [many pupils speaking in chorus] }\end{array}$ & $\begin{array}{l}\text { a very important factor } \\
\text { [many pupils speaking in chorus] }\end{array}$ \\
\hline $\begin{array}{l}432 \\
433 \\
434 \\
435\end{array}$ & TL & $\begin{array}{l}\text { fator ne'bé bo'ot liu } \\
\text { ita presiza liu né ga lae? } \\
\text { na movimentação } \\
\text { movimentação em Tétum?/2/ }\end{array}$ & $\begin{array}{l}\text { this factor is very important } \\
\text { do we need it or not? } \\
\text { for movement } \\
\text { movement in Tetum?/2/ }\end{array}$ \\
\hline 436 & PP & movimentu & movement \\
\hline 437 & PP & movimentu & movement \\
\hline $\begin{array}{l}438 \\
439\end{array}$ & PPS & $\begin{array}{l}\text { movimentu } \\
\text { [fewer pupils speaking in chorus] }\end{array}$ & $\begin{array}{l}\text { movement } \\
\text { [fewer pupils speaking in chorus] }\end{array}$ \\
\hline 440 & PP & movimentu & movement \\
\hline 441 & TL & portantu bele-? & therefore we can-? \\
\hline 442 & PP & movimentu & move \\
\hline 443 & $\mathbf{P P}$ & movimentu & move \\
\hline 444 & TL & halo movimen-? & to achieve movemen-? \\
\hline $\begin{array}{l}445 \\
446\end{array}$ & PPS & $\begin{array}{l}\text { movimentu } \\
\text { [many pupils speaking in chorus] }\end{array}$ & $\begin{array}{l}\text { movement } \\
\text { [many pupils speaking in chorus] }\end{array}$ \\
\hline $\begin{array}{l}447 \\
448 \\
449 \\
450 \\
451 \\
452 \\
453 \\
454 \\
455\end{array}$ & TL & $\begin{array}{l}\text { tetun movimentu bele iha tan tetun seluk } \\
\text { maibé imi sidauk coñece } \\
\text { movimentu } \\
\text { ita atu movimenta ba fatin ida } \\
\text { ita atu la'o } \\
\text { movimentu né la'o } \\
\text { né ga? } \\
\text { ita la'o ba fatin ida ita presiza iha } \\
\text { transpor-? }\end{array}$ & $\begin{array}{l}\text { there is another word in Tetum for } \\
\text { movement but you haven't learned it yet } \\
\text { movement } \\
\text { we move to another place } \\
\text { we move } \\
\text { movement is to move } \\
\text { right? } \\
\text { we move somewhere [and so] we need to have } \\
\text { transpor-? }\end{array}$ \\
\hline $\begin{array}{l}456 \\
457\end{array}$ & PPS & $\begin{array}{l}\text { transporte } \\
\text { [fewer pupils speaking in chorus] }\end{array}$ & $\begin{array}{l}\text { transport } \\
\text { [fewer pupils speaking in chorus] }\end{array}$ \\
\hline $\begin{array}{l}458 \\
459\end{array}$ & TL & $\begin{array}{l}\text { ba ema ne'bé fan merkadu liur } \\
\text { ba ema ne'bé so-? }\end{array}$ & $\begin{array}{l}\text { for people who sell in the open market } \\
\text { so that people can bu-? }\end{array}$ \\
\hline 460 & PPS & sosa [many pupils speaking in chorus] & buy [many pupils speaking in chorus] \\
\hline $\begin{array}{l}461 \\
462\end{array}$ & TL & $\begin{array}{l}\text { laos fan deit } \\
\text { ema ne'bé so-? }\end{array}$ & $\begin{array}{l}\text { it's not only for people to sell } \\
\text { but also for people to bu-? }\end{array}$ \\
\hline 463 & PPS & sosa [many pupils speaking in chorus] & buy [many pupils speaking in chorus] \\
\hline $\begin{array}{l}464 \\
465\end{array}$ & TL & $\begin{array}{l}\text { de uma região para outra } \\
\text { iha fatin ida ba fatin se-? }\end{array}$ & $\begin{array}{l}\text { from one region to another } \\
\text { from one region to ano-? }\end{array}$ \\
\hline 466 & PPS & seluk [many pupils saying in chorus] & another [many pupils saying in chorus] \\
\hline $\begin{array}{l}467 \\
468\end{array}$ & TL & $\begin{array}{l}\text { região } \\
\text { iha fatin ida ba fatin-? }\end{array}$ & $\begin{array}{l}\text { region } \\
\text { from one place to a-? }\end{array}$ \\
\hline 469 & PPS & seluk [many pupils saying in chorus] & another [many pupils saying in chorus] \\
\hline 470 & $\mathbf{P P}$ & ba fatin seluk & to another place \\
\hline
\end{tabular}

The verb la'o can mean 'go', 'move' or 'walk'

In Extract 5 above, we see that the pupils were having difficulty understanding the first sentence on the blackboard, with its abstract nouns. The extract shows how Teacher Lucia and the students addressed this challenge interactionally. Firstly, on three occasions, Teacher Lucia opened up the possibility of using Tetum by asking for a translation of particular terms (Lines 421, 423 and 435). Secondly, she elicited responses from the pupils by employing prompts of the 'complete my utterance' type. She did this in Tetum in eight different teacher initiation turns within this relatively short interactional sequence (Lines 
$429,441,444,455,459,462,465$ and 468). This clearly enabled the pupils to participate, either individually or in chorus. Thirdly, in lines 436 to 446, we see repetition of the term 'movimentu' (movement) and choral rehearsing of this key term in Tetum. As it happens, this term and the term 'transporte' are quite close in form to Portuguese, since they are loan words, so this provided additional support in gaining access to the meaning of the Portuguese text and the lesson content. And, fourthly, every now and then, Teacher Lucia incorporated elements of the Portuguese sentence on the board in her teacher initiations so that the pupils got to hear what they sounded like (e.g. lines 422-3, 428, 464 and 467).

Since the teachers and the pupils were dealing with textual knowledge and a language which they were not very familiar with, codeswitching served as a key communicative resource for connecting the textual knowledge and pupils' local knowledge as well as their linguistic knowledge. In these ways, Teacher Lucia helped her students to deal with the challenge of becoming familiar with the sound and graphic form of the Portuguese text on the board, of building an understanding of its meaning and, ultimately, gaining access to the content of the EM curriculum. This kind of codeswitching practice, aimed at meeting pupils' needs is similar to the one that Canagarajah (2001) described in his study in Jaffna. As we saw in Extracts 3-5, Teacher Lucia mediated the written text for her pupils by drawing on all the linguistic resources in her communicative repertoire, including Portuguese, Tetum and the local conventions of teacher talk. In elaborating on the text in Tetum, she made bridges between the language of the text and a language familiar to pupils growing up in Dili. Her frequent naming of Tetum as she asked for translations made it clear that she consented to its use as a language of teaching and learning.

However, the interactional practices captured in Extracts 3-5 were also contributing to the construction of the relative value of the two languages within the institutional context of the school. Portuguese was the language that really counted, as shown by Chimbutane (2011) in his research in post-colonial Mozambique. Portuguese was the language associated with textual knowledge and Tetum was used as an auxiliary language, for unpacking the EM lesson content. As in Cincotta-Segi's (2011) study in Laos, a local language was used by the teacher to make sense of the curriculum. When teacher Lucia's codeswitching practices were accompanied by the naming of languages, or when she attributed words to different languages this reflected a view of bilingualism as 'parallel monolingualisms' (Heller 2006, p. 271). Through her naming practices, Tetum and Portuguese were then represented as separate linguistic systems which 'coexisted' in the classroom. In this way, she was passing on to her pupils a view of languages as discrete and bounded entities rather than as flexible, blended and changing resources that can be adapted for different communicative practices.

The codeswitching practices of Teacher Lucia in this classroom in Timor-Leste are, of course, different from those that have been described and analysed in the studies in Jaffna, Mozambique or Laos cited above. The political and sociolinguistic realities of those countries differ considerably from those in Timor-Leste. The practices I have described in this article have to be situated within the specific nationbuilding processes unfolding in Timor-Leste in its first decade as an independent nation. The processes of re-appropriating the two official languages, Tetum and Portuguese, and of assigning new values to them (processes that had their roots in the 
years of the East-Timorese Resistance to the Indonesian occupation) were complex and challenging ones.

\section{Concluding remarks}

Schools in the post-colonial context of Timor-Leste are particularly interesting research sites due to the multilingual environment, and due to the fact that a national bilingual/multilingual policy is still in the process of being implemented after years of occupation by external forces that imposed strict monolingual policies. Moreover, this national policy is being implemented in a global age: teaching materials in Portuguese are being created in Portugal and support for the training of Portuguese teachers is being provided through multi-lateral cooperation programmes with Brazil and Portugal, while few initiatives have been taken with a view to developing materials for Tetum teaching, or even bilingual materials. My aim has been to show that it is necessary to take into account these complex post-independence conditions, and the discourses articulated at the national level, in order to understand the challenges involved in introducing the new language policy into primary school classrooms in Timor-Leste and in reshaping communication in classrooms. For this reason, I have described and analysed language policy processes at work on different scales.

Firstly, I charted the changes that have taken place overtime in the language-ineducation policy since independence in 2002 in Timor-Leste and I noted the importance of assistance from countries such as Portugal and Brazil in the design, and the development of curriculum, in teacher training and in materials development. The significance of international aid programmes in the development of education in Timor-Leste was a key theme in the political discourse in the years immediately following independence.

Secondly, I analysed the ways in which the language-in-education policy was being interpreted by two social actors who were closely involved in language policy making on the national scale. Dr Santos argued for the use of Portuguese as the main medium of instruction, with Tetum as the auxiliary language. He represented Tetum as a 'developing' language which has pedagogic and didactic uses, but should be accompanied by the use of Portuguese. His representation of Portuguese and Tetum as being intricately intertwined echoed the views of an Australian linguist who had been involved in early discussions about language policy in Timor-Leste. Mr Mota took the pragmatic view that it was appropriate for two languages to be used in the classroom in the early stage of implementation, but his aspiration was for lessons to eventually be monolingual in Portuguese. In the views of both policymakers, Portuguese was clearly assigned much more prestige and symbolic value in education.

Thirdly, I took a close look at the views of one teacher and at her classroom practices and I interpreted her views and practices in the light of her background and her beliefs about the language-in-education policy. Teacher Lucia revealed in her classroom practices, and in her interviews, that she saw both Tetum and Portuguese as valuable resources for primary education in Timor-Leste. Her values and beliefs were aligned with the broad language ideologies of Dr Santos and Mr Mota, 
although she did not anticipate any shift towards monolingual classroom practices. Teacher Lucia was observing the national language-in-education policy by using the two languages as mandated in the policy and curriculum documents. However, her use of the textbook in Portuguese, and her use of Tetum as an auxiliary language as she mediated the textbook in Portuguese, as she attended to pupils' preferences and needs, conveyed the idea that Portuguese was the legitimate language (Bourdieu 1991) of the curriculum and the main target language. Portuguese was thus assigned a higher value than Tetum and Tetum was treated as an auxiliary language. Yet, for teacher Lucia they complemented each other. Despite the continued visibility of Bahasa-Indonesia in social life in Timor-Leste and despite the more fluid linguistic practices in everyday communicative practices outside the classroom (including the use of resources from Tetum, Portuguese, English and Indonesian), these ways of speaking practices were mostly omitted from this particular classroom (with the exception of established loan words from Indonesian, such as biskota (city bus)). Codeswitching between Tetum and Portuguese was the main pedagogic strategy that Teacher Lucia observed most regularly in her talk around monolingual Portuguese texts.

Lastly, I showed, in this article, that both the discourses of policymakers about the language-in-education policy and some of Teacher Lucia's pedagogic practices (e.g. her naming of the languages) revealed a longstanding ideology which has been shaping nation-building projects in diverse multilingual education settings around the world: That is, the belief that named languages are stable and bounded entities. As many scholars (e.g. Heller 2007; Lin 2013) have shown, these ideologies of bilingualism are associated with powerful political and academic discourses about language being tied to nation and identity.

The implementation of the language-in-education policy in primary schools in Timor-Leste has been a challenging process since 1999, as shown by other scholars (Cabral 2013; Taylor-Leech 2013). At the time when I was conducting my fieldwork, the small number of trained teachers who were proficient in Portuguese, the large population of school age, the limited number of schools, overcrowded classrooms and the paucity of materials in either Portuguese or Tetum were often cited as the major challenges in the implementation of the new language-in-education policy. This article has illustrated the ways in which EastTimorese teachers, like teacher Lucia, were endeavouring to implement this language policy despite the general educational conditions.

Both Portuguese and Tetum are valuable for social mobility in Timor-Leste. Teachers should be thus encouraged to provide pupils with access to both languages regardless of the linguistic resources they bring into the classroom. The current investment in the initial training of Portuguese language teachers in Timor-Leste should cover not only how to teach in Portuguese, but also how to develop bilingual educational pedagogies including the use of Tetum and/or other languages that are familiar to the teachers and pupils. Following Arthur's (2001) recommendation, based on her research in Botswana primary schools, I argue for the acceptance of the pedagogical use of codeswitching as a communicative strategy in classrooms and the acknowledgment of its value, instead of seeing it as a reflection of lack of language abilities on the part of teachers. Codeswitching 
is the language teaching strategy that is familiar to teachers like Teacher Lucia, and it should be more fully understood. More research needs to be developed, to document the patterns that recur, along with their meaning-making potential. Ideally, research of this kind would involve close collaboration between researchers and educational practitioners in Timor-Leste.

The primary school curriculum also needs to include materials which familiarise the students with different genres and registers of Tetum, in both spoken and written modes. The language also needs to be recognised as a key resource for knowledge-building.

In addition, teacher education in Timor-Leste needs to take fuller account of the wider sociolinguistic environment beyond the school gates and the communicative repertoires of both teachers and students. Fluid linguistic practices are an intrinsic part of everyday life in this multilingual nation. East-Timorese spontaneously mix resources from local languages, like Tetum, with Portuguese, Bahasa-Indonesia and English, while focusing on named languages as separate, fixed and bounded object in the schools. This tension between fluidity and fixity lies at the heart of education in multilingual nations, such as Timor-Leste. As Jaspers and Madsen (2019) point out, linguistic fixity and fluidity are actually "part of the same linguistic culture ... their mutual association ... invites dilemmas in everyday life and academia" (p.16). Jaspers and Madsen also acknowledge the "enduring, social value of separate languages" (Ibid). The linguistic culture of multilingual Timor-Leste includes both separated and fluid linguistic practices, and enduring language ideologies about Portuguese and Tetum. These sociolinguistic realities should be taken into account in teacher training at universities in Timor-Leste. ${ }^{4}$

Open Access This article is licensed under a Creative Commons Attribution 4.0 International License, which permits use, sharing, adaptation, distribution and reproduction in any medium or format, as long as you give appropriate credit to the original author(s) and the source, provide a link to the Creative Commons licence, and indicate if changes were made. The images or other third party material in this article are included in the article's Creative Commons licence, unless indicated otherwise in a credit line to the material. If material is not included in the article's Creative Commons licence and your intended use is not permitted by statutory regulation or exceeds the permitted use, you will need to obtain permission directly from the copyright holder. To view a copy of this licence, visit http://creativecommons.org/licen ses/by/4.0/.

\footnotetext{
4 Transcription conventions.

Teacher Lucia - TL.

Pupils - PPS.

Pupil - PP.

FP - Female Pupil.

MP - Male pupil.

Plain font - in Portuguese.

Bold - in Tétum (in the original transcript and in the translation).

-? - teacher prompt of the 'complete my utterance type'.

/2//10/- Length of pause - in seconds.

[] - Researcher's comments.
} 


\section{References}

Arthur, J. (2001). Codeswitching and collusion: Classroom interaction in Botswana primary schools. In M. Heller \& M. Martin-Jones (Eds.), Voices of authority: Education and linguistic difference (pp. 58-75). Westport, CT: Ablex.

Blackledge, A. (2000). Language ecology and language ideology. In A. Creese, P. Martin, \& N. H. Hornberger (Eds.), Encyclopedia of language and education (2nd ed., pp. 27-40)., Volume 9: Ecology of language Berlin: Springer.

Blackledge, A. (2011). Linguistic ethnography. In M. Grenfell (Ed.), Bourdieu, language and linguistics (pp. 121-146). London: Continuum.

Blackledge, A., \& Creese, A. (2010). Multilingualism: A critical perspective. London: Continuum.

Blommaert, J. (1994). Metaphors of development and modernization. In R. Fardon \& G. Furniss (Eds.), African languages, development and the state (pp. 213-226). London and New York: Routledge.

Blommaert, J. (2006). Language ideology. In K. Brown (Ed.), Encyclopedia of language and linguistics (2nd ed., Vol. 6, pp. 510-522). Hoboken: Elsevier.

Blommaert, J. (2007). On scope and depth in linguistic ethnography. Journal of Sociolinguistics, 11(5), $682-688$.

Bonacina, F., Da Costa Cabral. I., \& Huang, J (forthcoming) A state-of-the-art review of translanguaging in education. Language Teaching.

Bourdieu, P. (1991). Language and symbolic power. Cambridge: Cambridge University Press.

Cabral, E. (2013). The development of language policy in global age: The case of East-Timor. In J. A. Shoba \& F. Chimbutane (Eds.), Bilingual education and language policy in the global south (pp. 83-103). New York and London: Routledge.

Cabral, E. (2019). Timor-Leste 1974-1975: Decolonisation, a nation-in-waiting and an adult literacy campaign. International Journal of the Sociology of Language, 259, 39-61.

Cabral, E., \& Martin-Jones, M. (2008). Writing the resistance: Literacy in East-Timor 1975-1999. International Journal of Bilingual Education and Bilingualism, 11(2), 149-169.

Canagarajah, S. (2001). Constructing hybrid postcolonial subjects: codeswitching in Jaffna classrooms. In M. Heller \& M. Martin-Jones (Eds.), Voices of authority: Education and linguistic difference (pp. 193-212). Westport, CT: Ablex Publishing.

Canagarajah, S. (2013). Translingual practices: Global Englishes and cosmopolitan relations. New York: Routledge.

Carneiro, A. S. (2015). Conflicts around the (de)construction of legitimate language(s): The situation of Portuguese in the multilingual context of East-Timor. In L. P. Moita Lopes (Ed.), Global Portuguese: Linguistic ideologies in late modernity (pp. 204-221). New York: Routledge.

Chimbutane, F. (2011). Rethinking bilingual education in postcolonial contexts. Bristol: Multilingual Matters.

Chimbutane, F. (2013). Codeswitching in L1 and L2 contexts: Insights from a study of teacher beliefs and practices in Mozambican bilingual education programmes. Language and Education, 27(4), 314-328.

Chimbutane, F. (2019). Micro-language planning and agency in the context of bilingual education provision in Mozambique. In J. Bouchard \& G. P. Glasgow (Eds.), Agency in language policy and planning: Critical inquiries (pp. 77-99). New York: Routledge.

Cincotta-Segi, A. R. (2011). Signalling L2 centrality, maintaining L1 dominance: teacher language choice in an ethnic minority primary classroom in the Lao PDR. Language and Education, 25(1), 19-31.

Constituent Assembly. (2002). Constitution of the Democratic Republic of Timor-Leste (Section 13). Dili: Timor-Leste.

Copland, F., \& Creese, A. (2015). Linguistic ethnography. London: Sage.

Creese, A. (2008). Linguistic ethnography. In K. A. King \& N. H. Hornberger (Eds.), Encyclopedia of language and education (2nd ed., pp. 229-241)., Volume 10: Research methods in language and education Berlin: Springer.

Creese, A., \& Blackledge, A. (2015). Translanguaging and identity in educational settings. Annual Review of Applied Linguistics, 35, 20-35.

Da Costa Cabral, I. (2019). 'As linguas têm de estar no seu devido lugar' ('languages have to be in their proper place'): Language ideologies, languagised worlds of schooling and multilingual classroom practices in Timor-Leste. Current Issues in Language Planning, 20(1), 33-49.

García, O. (2009). Bilingual education in the 21st Century: A global perspective. Malden: Blackwell. 
Gumperz, J. (1982). Discourse strategies. Cambridge: Cambridge University Press.

Heller, M. (2006). Linguistic minorities and modernity: A sociolinguistic ethnography (2nd ed.). London: Continuum.

Heller, M. (Ed.). (2007). Bilingualism: A social approach. London: Palgrave.

Heller, M., \& Martin-Jones, M. (2001). Voices of authority: Education and linguistic difference. Westport, CT: Ablex Publishing.

Hornberger, N. H. (1988). Bilingual education and language maintenance: A southern Peruvian Quechua case. Berlin: Mouton De Gruyter.

Hornberger, N. H., \& Johnson, D. C. (2007). Slicing the onion ethnographically: Layers and spaces in multilingual language education. TESOL Quarterly, 41(3), 509-532.

Hull, G. (2000). East Timor: Identity, Language and Educational Policy, English translation of address to the CNRT National Congress 25 August.

Hult, F. (2015). Making policy connections across scales using nexus analysis. In F. Hult \& D.C. Johnson (Eds.), Research methods in language policy and planning: A practical guide (pp. 217-231). Wiley and Sons Inc.

Jaffe, A. (2003). Talk around text: Literacy practices, cultural identity and authority in a Corsican bilingual classroom. International Journal of Bilingual Education and Bilingualism, 6(3-4), 202-220.

Jaspers, J., \& Madsen, L. M. (Eds.). (2019). Critical perspectives on linguistic fixity and fluidity: Languagised lives. New York: Routledge.

Johnson, D. C. (2009). Ethnography of language policy. Language Policy, 8, 139-159.

Johnson, D. C. (2013). Language policy. Basingstoke: Palgrave Macmillan.

Jørgensen, J. N. (2008). Polylingual languaging around and among children and adolescents. International Journal of Multilingualism, 5(3), 161-176.

Keating, C. (2019). Discourses about language and literacy education in Portugal: Past and present. International Journal of the Sociology of Language, 259, 15-38.

Leach, M. (2008). Surveying East Timorese tertiary student attitudes to national identity: 2002-2007. South East Asia Research, 16(3), 405-431.

Lin, A. M. Y. (2008). Codeswitching in the classroom: Research paradigms and approaches. In K. A. King \& N. H. Hornberger (Eds.), Encyclopedia of language and education (2nd ed., pp. 273-286)., Volume 10: Research methods in language and education Berlin: Springer.

Lin, A. M. Y. (2013). Breaking the hegemonic knowledge claims in language policy and education: 'The global south as method. In J. A. Shoba \& F. Chimbutane (Eds.), Bilingual education and language policy in the global south. New York: Routledge.

Luke, A. (1988). Literacy, textbooks and ideology. London: Falmer.

Makoni, S. B., \& Severo, C. (2015). Lusitanization and Bakhtinian perspectives on the role of Portuguese in Angola and East Timor. Journal of Multilingual and Multicultural Development., 36(2), 151-162.

Martin-Jones, M. (1995). Code-switching in the classroom: two decades of research. In L. Milroy \& P. Muysken (Eds.), One speaker, two languages: cross-disciplinary perspectives on code-switching (pp. 90-111). Cambridge: CUP.

Martin-Jones, M. (1997). Bilingual classroom discourse: Changing research approaches and diversification of research sites. In N. H. Hornberger \& D. Corson (Eds.), Encyclopedia of language and education., Volume 8: Research methods in language and education Cambridge: Kluwer Academic Publishers.

Martin-Jones, M. (2015). Multilingual classroom discourse as a window on wider, social, political and ideological processes: Critical ethnographic approaches. In N. Markee (Ed.), The handbook of classroom discourse and interaction (pp. 446-460). Chichester: Wiley.

McCarty, T. L. (Ed.). (2011). Ethnography of language policy. London: Routledge.

Ministry of Education (MoE) (2008). Education system framework law 14/2008 (Government of TimorLeste). Dili, East-Timor: MoE and República Democrática de Timor-Leste (RDTL). Retrieved from, http://pt.scribd.com/doc/35236407/Structure-Ministry-Education-English. Accessed 15 June 2015.

Ministry of Education, Culture, Youth and Sport (MECYS) (2004). Education Policy 2004-2009, Dili, East-Timor: MECYS and República Democrática de Timor-Leste (RDTL).

Moura, P. (2007). Público. Retrieved February 25, 2020, from https://www.publico.pt/2007/05/07/jornal/ portugues-tetum-ou-tetugues-a-politica-da-lingua-em-timor-213807.

Nicolai, S. (2004). Learning independence: Education in emergency and transition in East Timor since 1999. Paris: International Institute for Educational Planning.

Otsuji, E., \& Pennycook, A. (2010). Metrolingualism: Fixity, fluidity and language in flux. International Journal of Multilingualism, 7(3), 240-254. 
Rampton, B. (2007). Neo-Hymesian linguistic ethnography in the United Kingdom. Journal of Sociolinguistics., 11(5), 584-607.

Ricento, T. L., \& Hornberger, N. H. (1996). Unpeeling the onion: language planning and policy and the ELT professional. TESOL Quarterly, 30(3), 401-428.

Schieffelin, B. B., Woolard, K., \& Kroskrity, P. V. (1998). Language ideologies: practice and theory. New York: Oxford University Press.

Shah, R. (2012). Goodbye conflict, hello development? Curriculum reform in Timor-Leste. International Journal of Educational Development., 32, 31-38.

Snell, J., Shaw, S. E., \& Copland, F. (2015). Linguistic ethnography: Interdisciplinary explorations. Basingstoke: Palgrave Macmillan.

Solovova, O. (2019). Opening up ideological spaces for multilingual literacies at the margins of the Portuguese education system? Ethnographic insights from a Russian complementary school. International Journal of the Sociology of Language, 259, 161-190.

Taylor-Leech, K. (2009). The language situation in Timor-Leste. Current Issues in Language Planning, $10(1), 1-68$.

Taylor-Leech, K. (2013). Finding space for non-dominant languages in education: language policy and medium of instruction in Timor-Leste 2000-2012. Current Issues in Language Planning, 14(1), 109-126.

Tollefson, J. W., \& Pérez-Milans, M. (2018). The Oxford handbook of language policy and planning. New York: Oxford University Press.

Vidal Soares, L. (2011). Qual é o papel da língua portuguesa na política educativa de Timor-Leste? In A. B. da Costa \& A. Barreto (Eds.), COOPEDU: Congresso Portugal e os PALOP Cooperação na Área da Educação. Lisbon: CEA, ISCTE-IUL.

Woolard, K. (1998). Introduction: Language ideology as a field of inquiry. In B. Schieffelin, K. Woolard, \& P. Kroskrity (Eds.), Language ideologies: Practice and theory (pp. 3-47). New York: Oxford University Press.

Zentella, A. C. (1981). 'Ta bien, you could answer me en qualquier idioma': Puerto Rican codeswitching in bilingual classrooms. In R. Duran (Ed.), Latino language and communicative behavior (pp. 109-132). Norwood, NJ: Ablex.

Publisher's Note Springer Nature remains neutral with regard to jurisdictional claims in published maps and institutional affiliations.

Ildegrada da Costa Cabral has taught and supervised theses at Masters level at the University of Birmingham and the University of Nottingham (UK) since 2016. She was awarded a PhD in the School of Education at the University of Birmingham in 2015. In her doctoral research she undertook a multi-scalar investigation of language policy processes in Timor-Leste. Her current research interests include bilingual classroom discourse, linguistic ethnography, language policy processes, multilingualism and transnational migration. Her published research has appeared in The AILA Review, International Journal of Multilingualism, and Current Issues in Language Planning. She is a speaker of Tetum, Portuguese and English.

\section{Affiliations}

\section{Ildegrada da Costa Cabral ${ }^{1}$}

Ildegrada da Costa Cabral

ildeccabral@gmail.com

1 Nottingham, UK 